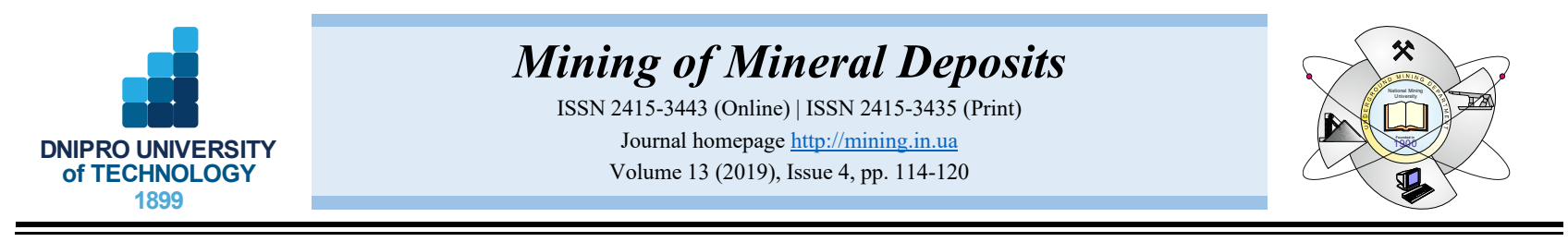

UDC 622.234 .42

https://doi.org/10.33271/mining13.04.114

\title{
STUDY OF CHANGE IN THE LEACHING SOLUTION ACTIVITY AFTER TREATMENT WITH A CAVITATOR
}

\author{
E. Aben ${ }^{1}$, Zh. Markenbayev ${ }^{2}$, N. Khairullaev ${ }^{1 *}$, S. Myrzakhmetov ${ }^{1}$, Kh. Aben ${ }^{3}$ \\ ${ }^{1}$ Satbayev University, Almaty, Kazakhstan \\ 2 "DP "Ortalyk" LLP, Shymkent, Kazakhstan \\ ${ }^{3}$ KAZ Minerals, Almaty, Kazakhstan \\ *Corresponding author: e-mail khayrullaev.n@gmail.com,tel.+77751833333
}

\begin{abstract}
Purpose. Increasing the valuable component content in a pregnant solution due to the activation of leaching solution with cavitation treatment in case of the borehole in-situ leaching (ISL).

Methods. To obtain the cavitation effect, a laboratory cavitation plant has been produced. Studies on the sulphuric acid solution activation by means of cavitation were conducted using solutions with $10 \mathrm{~g} / \mathrm{l}$ of acid content. Studies of changing the sulphuric acid solution activity during treatment with a cavitator were conducted for 3 minutes ( 24 passes through the cavitator), 5 minutes (40 passes), 10 minutes ( 80 passes) and 20 minutes (160 passes). The content in the solution of the valuable component was analysed using a KFK-3-“ZOMS" photoelectric photometer.
\end{abstract}

Findings. The laboratory studies have been performed to set the influence of the cavitation process on the leaching solution activity at various degrees of activation and time of reaction. The studies have established that in order to activate the leaching solution, it is proposed to carry out cavitation treatment of sulphuric acid before to additionally fortify the mother solution, which helps to increase its activity. The solution activation leads to an increase in the valuable component content from 18 to $26 \%$ in the pregnant solution and its activity is maintained for a long time (up to 30 days).

Originality. New dependences have been obtained reflecting the nature of changing the valuable component content in the pregnant solution on the reaction time and the degree of solution activation.

Practical implications. The proposed activation method leads to an increase in the valuable component content in the pregnant solution compared to the basic technology, therewith, the activity is maintained for a long time. The proposed technology is characterized by low capital costs, is easily integrated into the existing system and is absolutely environmentally friendly.

Keywords: cavitation, activity, sulphuric acid, leaching solution, productive solution, conventional metal

\section{INTRODUCTION}

Currently, the poor deposits of hydrogen genesis, occurring in permeable sand-clay deposits of the depressed zones in the earth's crust are mainly the raw material base for enterprises mining uranium by underground leaching (Sukhodolov, 2010), and the poor and off-balance ores are the raw material base for mining gold by heap leaching (Karaganov \& Uzhkenova, 2002). Until recently, these deposits, containing reserves of uranium and gold, have not been involved in industrial development by traditional mining methods for technical and economic reasons. This important task, which is of great economic importance, by now has been largely solved (Menshov et al., 2016; Medunić, Mondol, Rađenović, \& Nazir, 2018; Sukhov,
Suyarko, Niemets, \& Matveyev, 2018; Anisimov, Symonenko, Cherniaiev, \& Shustov, 2018). Especially in the last decade, great work has been done on the development and industrial implementation of geotechnological mining of uranium, called the method of underground leaching (UL) (Kalabin, 1981; Arens, 1986; Armstrong \& Jeuken, 2009; Catchpole \& Robins, 2015), and gold by the method of heap leaching (Kashuba \& Leskov, 2014) with reclamation of the mined-out space (Kalybekov, Sandibekov, Rysbekov, \& Zhakypbek, 2019).

Underground leaching of uranium is carried out by selective its dissolution with chemical reagents from ores at the place of their occurrence and subsequent extraction from uranium-containing solutions. Despite all the advantages, when using a borehole in-situ leaching of

(C) 2019. E. Aben, Zh. Markenbayev, N. Khairullaev, S. Myrzakhmetov, Kh. Aben. Published by the Dnipro University of Technology on behalf of Mining of Mineral Deposits. This is an Open Access article distributed under the terms of the Creative Commons Attribution License (http://creativecommons.org/licenses/by/4.0/),

which permits unrestricted reuse, distribution, and reproduction in any medium, provided the original work is properly cited. 
uranium, there is still a number of unresolved problems, one of which is to prolong the interrepair cycle of production wells performance, as well as to increase the ratio of uranium recovery (Zabel'skiy, 1981; Golik \& Kultyshev, 2011; Yusupov, Elzhanov, Aliev, \& Dzhakupov, 2017; Shcherbakov, Tymchenko, Buhrym, \& Klymenko, 2019).

Heap leaching is used to obtain valuable components (primarily metals) by dissolving prepared (crushed offbalance ores and dumps of poor ores or the dressing plant tailings) and specially stacked mineral raw materials, with their subsequent allocation (Ye, Ding, Li, Song, \& Li, 2013; Petersen, 2016; Hoummady et al., 2017). This process application makes it possible to involve into production the poor and off-balance ores, overburden rocks of quarries and mature tailings of dressing plants (Barchenkov, 2016; Sekisov, Rubtsov, \& Lavrov, 2016). However, despite all the advantages, a significant drawback of this leaching method is the low recovery ratio, the duration of the leaching process and the dependence on climatic conditions.

Therefore, the purpose of the work is to increase the valuable component content in the pregnant solution by activating the leaching solution in borehole in-situ leaching. To increase the efficiency, it is proposed to leach by the activated solution with cavitation before it is supplied to the ore massif (Knepp, Deyli, \& Khemmit, 1974; Lauterborn, 1980).

Cavitation is the process of vapour generation and subsequent collapse of vapour bubbles with simultaneous vapour condensation in the fluid stream, accompanied by noise and hydraulic shocks, the formation of cavities in the fluid (cavitation bubbles, or caverns) filled with vapour of the very fluid in which it occurs. Cavitation occurs as a result of a local pressure decrease in the liquid, which can occur either with an increase in its velocity (hydrodynamic cavitation) or with the passage of a highintensity acoustic wave during the rarefaction half-period (acoustic cavitation). There are other reasons for the effect to occur. Being moved with the stream to an area with a higher pressure or during a compression halfperiod, the cavitation bubble collapses, emitting at the same time a shock wave (Kubota, Kato, \& Yamaguchi, 1992; Vogel, Busch, \& Parlitz, 1996; Prentice, Cuschieri, Dholakia, Prausnitz, \& Campbell, 2005).

The leading role in the formation of bubbles in cavitation is played by gases evolving inside the resulting bubbles. These gases are always contained in the fluid, and with a local decrease in pressure, they begin to be intensively evolved inside these bubbles. It should also be taken into account that gases dissolved in the fluid contain more oxygen as a percentage wise than in air. Therefore, the gases in bubbles during cavitation are chemically more aggressive than atmospheric air - as a result, they induce oxidizing (tendency to react) of many usually inert materials. Collapsing the cavitation bubbles leads to the fact that the energy of the surrounding fluid is concentrated in very small volumes (Miller, 2007; Ceccio, 2010; Rooze, Rebrov, Schouten, \& Keurentjes, 2013).

The degree of treatment of the solution by cavitator is assessed either according to changing the density before and after cavitator, or increasing the temperature of the solution. The technology does not require significant capital and operating costs, moreover, there is an ability to integrate into existing infrastructure. To achieve this goal, it is necessary: study the cavitation effect, conduct laboratory studies on the influence of activated leaching solution on increasing the degree of extraction during underground leaching; statistically process and analyse the research results.

Treatment of various types of materials using cavitators always has a positive effect. Application of cavitation is described in an extremely wide range: obtaining emulsions, destroying and removing contaminants, obtaining inorganic and organic compounds, activating the fuel, the latest torpedo designs, etc. But, with such a wide range of the cavitation effect application, there are no single methods for assessing the effectiveness of this phenomenon. The proposed mathematical expressions give a non-dimensional coefficient, which in no way reflects a change in the treated material properties. In fact, in each individual case, the effectiveness of cavitation is assessed according to changing the final results.

One of the changing parameters during treatment of a liquid with cavitator is an increase in the temperature of the solution to be treated. It is obvious that the temperature increase is a proxy indicator of the energy transmitted by the cavitator to the electrolyte (Koshkolda, Pimenov, Atakulov, 1988; Wadsworth, Zhu, Thompson, \& Pereira, 2000; Tan, Deng, \& Li, 2016).

\section{METHODS}

Based on the specific task set in this work, the main characteristic for its implementation is the activity of the leaching solution in the interaction with ore and rock materials. Therefore, the main indicator during laboratory research is the change in the solution activity using various methods of its treatment.

The studies on the sulphuric acid solution activation by means of cavitation described above have been made on solutions with an acid content of $10 \mathrm{~g} / \mathrm{l}$. However, given the large volume of leachable solution supplied under industrial conditions, which requires significant energy costs for its mechanical activation, we have studied the possibility of activating the concentrated sulphuric acid used to fortify the mother solution. Then, the experiments were conducted using the solution prepared with the activated acid. Treated solutions were tested for leaching of conventional metal. In the experiments, the operating time of the cavitating plant was increased and adjusted to 30 minutes. Hereunder, the research results are presented of changing the sulphuric acid solution activity during treatment with a cavitator for 3 minutes (24 passes through the cavitator), 5 minutes (40 passes), 10 minutes (80 passes) and 20 minutes (160 passes).

The solution of acid and water was mixed by turning on the pump for 15 seconds, which corresponds to approximately twofold passing the entire volume of liquid in the plant through the cavitator. The solution mixed in this way was taken as the initial one and an initial study of the leaching intensity was conducted on it. Then, the solution in the plant was exposed to treating for a certain time, after which the samples were immediately taken for the leaching experiment, and the main volume was 
poured into a separate container and samples were subsequently taken after a certain time for repeated studies with the same solution.

As the main indicator of the cavitator action efficiency, not the absolute value of content of the conventional metal in the leaching solution was used, but a change in activity on a percentage base relative to the initial electrolyte. Based on the analysis of the data obtained when studying the influence of temperature on the activity of the solution, the time was chosen for sampling in leaching for 5, 10, 20 and 30 minutes. Five minutes of leaching time was accepted as the main indicator.

To obtain the cavitation effect, a cavitation plant has been produced (Fig. 1). The laboratory plant consists of a closed loop circuit, which includes a centrifugal type pump $(P)$ with an electric motor drive, a flow-through cavitator $(R)$, a pipeline, a container $(V)$, a discharge cock $(K)$.

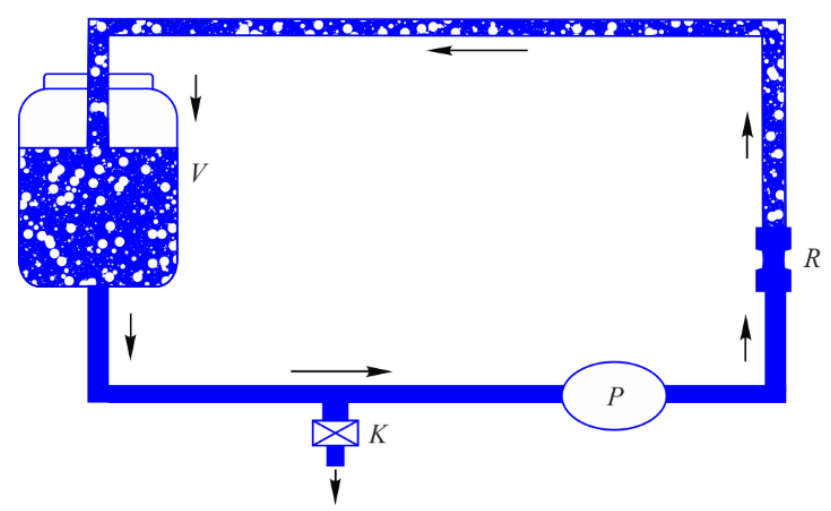

Figure 1. Laboratory cavitation plant

The plant was poured with 1.5 litres of acid, and it was treated for 5 minutes after that. Then, a solution with a content of $10 \mathrm{~g} / \mathrm{l}$ was prepared from activated acid. Thereafter, its activity was tested when leaching. The results were compared with the same experiment, but without prior activating the acid.

One of the aqueous solutions (electrolytes) characteristics is viscosity. To obtain comparative data on the relative viscosity, the VU GOST 1532-81 viscometer was used with built-in preheating. The viscosity was measured by the time of the solution flowing out of the viscometer with the registration of a stop-watch timer.

The valuable component content in the solution was analysed using a KFK-3-"ZOMS" photoelectric photometer. Initially, according to the instructions for using the photometer, the working light frequency in the device, equal to $800.2 \mathrm{~nm}$, was determined based on the $\mathrm{CuSO}_{4}$ solution. Then, using the solutions of conventional metal with a concentration of $1,3,5$ and $10 \mathrm{~g} / 1$, the device was calibrated. Then, it became possible, when leaching, to use the ratio coefficient $C / A=3.03$ for current calculations of the conventional metal content in solutions. Experimentally using a thermometer, it was determined that to achieve the temperature of the experiment, the preliminary mixing time is in the range of $7-10$ minutes. After that, a sample weight of a conventional metal was placed into the solution, and after a certain time the solution sample was taken for analysis. To purify the sample solution from the particles of the conventional metal contained in it, the sample was fil- tered and placed into the photometer cuvette. A photometer with a preliminary set light frequency was turned on and held for at least 30 minutes before measuring the optical density of the solution. Before to start a series of experiments on leaching, preliminary experiments have been made, according to the results of which a solution volume for leaching of $150 \mathrm{ml}$, a stirrer rotation velocity of $45 \mathrm{rpm}$ and time of leaching were selected. By calculations, it was determined that at a concentration of $10 \mathrm{~g} / \mathrm{l}$ of sulphuric acid in the solution, a sample weight of the conventional metal may be $1.2 \mathrm{~g}$.

\section{RESULTS AND DISCUSSION}

The results of measuring the conventional metal content in the solutions after leaching revealed that the acid activity after cavitation treatment has increased by $14 \%$. Therefore, there is no need in industrial conditions to perform the mechanical activation of the entire leaching solution, it is enough to treat with fortifying concentrated sulphuric acid. This dramatically reduces the energy costs. The research results of changing the leaching solution activity during treatment with a cavitator for 3 minutes are presented in Table 1 and in Figure 2.

Table 1. Changing the optical density (A) over time and the conventional metal content in the leaching solution (C) after treatment of the electrolyte with a cavitator for 3 minutes

\begin{tabular}{|c|c|c|c|c|c|}
\hline \multirow{2}{*}{$\begin{array}{l}\text { Parame- } \\
\text { ters }\end{array}$} & \multicolumn{4}{|c|}{ Reaction time, min } & \multirow{2}{*}{$\begin{array}{c}\text { Type and time } \\
\text { of the solution } \\
\text { mature }\end{array}$} \\
\hline & 5 & 10 & 20 & 30 & \\
\hline$A$ & 1.365 & 1.431 & 1.521 & 1.553 & Initial \\
\hline$C, \mathrm{~g} / 1$ & 4.08 & 4.33 & 4.61 & 4.70 & solution \\
\hline$A$ & 1.508 & 1.534 & 1.591 & 1.61 & After \\
\hline$C, \mathrm{~g} / 1$ & 4.78 & 5.80 & 5.18 & 5.23 & treatment \\
\hline$A$ & 1.420 & 1.492 & 1.530 & 1.596 & 2 hours after \\
\hline$C, \mathrm{~g} / \mathrm{l}$ & 4.48 & 4.51 & 5.08 & 5.22 & treatment \\
\hline$A$ & 1.417 & 1.502 & 1.564 & 1.616 & 24 hours after \\
\hline$C, \mathrm{~g} / \mathrm{l}$ & 4.29 & 4.55 & 4.74 & 4.90 & treatment \\
\hline$A$ & 1.445 & 1.532 & 1.669 & 1.669 & 30 days after \\
\hline$C, \mathrm{~g} / 1$ & 4.45 & 4.76 & 5.06 & 5.1 & treatment \\
\hline
\end{tabular}

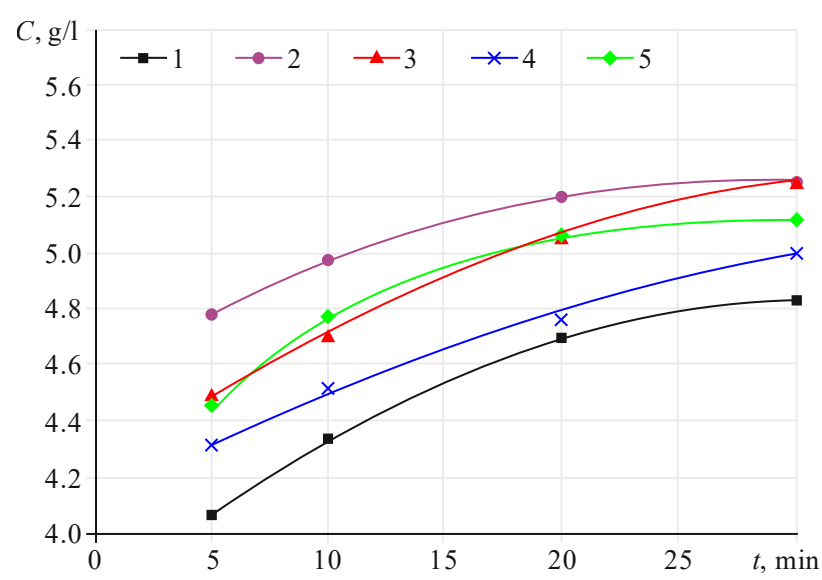

Figure 2. Changing the content of conventional metal in the leaching solution depending on the time of reaction and the solution mature over time after treatment with a cavitator for 3 minutes: 1 -initial state of the solution (before treatment); 2-after treatment; 3-2 hours after treatment; 4-24 hours after treatment; 5 - 30 days after treatment 
From the analysis of Table 1, it follows that the treatment held of the solution has led to a primary increase in leaching for 5 minutes by $17 \%$. There was not an expected significant decrease in the solution activity after holding it over time. The curves presented in Figure 2 show that the greatest changes in the conventional metal content in the solution are observed at a time of leaching for 5 minutes, and then this differential decreeses. In the course of the solution treatment with a cavitator, there was some evolution of sulphur dioxide (odour).

The data on the solution activity after treatment with a cavitator for 5 minutes is presented in Table 2 and in Figure 3.

Table 2. Changing the optical density (A) over time and the conventional metal content in the leaching solution (C) after treatment of the electrolyte with a cavitator for 5 minutes

\begin{tabular}{|c|c|c|c|c|c|}
\hline \multirow{2}{*}{$\begin{array}{l}\text { Parame- } \\
\text { ters }\end{array}$} & \multicolumn{4}{|c|}{ Reaction time, $\min$} & \multirow{2}{*}{$\begin{array}{c}\text { Type and time } \\
\text { of the solution } \\
\text { mature }\end{array}$} \\
\hline & 5 & 10 & 20 & 30 & \\
\hline$A$ & 1.323 & 1.398 & 1.468 & 1.542 & Initial \\
\hline$C, \mathrm{~g} / 1$ & 4.06 & 4.23 & 4.45 & 4.67 & solution \\
\hline$A$ & 1.403 & 1.475 & 5.23 & 5.70 & After \\
\hline$C, \mathrm{~g} / 1$ & 4.9 & 5.10 & 4.90 & 5.09 & treatment \\
\hline$A$ & 1.340 & 1.432 & 1.531 & 1.587 & 2 hours after \\
\hline$C, \mathrm{~g} / 1$ & 4.80 & 5.06 & 5.34 & 5.16 & treatment \\
\hline$A$ & 1.380 & 1.456 & 1.529 & 1.611 & 24 hours after \\
\hline$C, \mathrm{~g} / \mathrm{l}$ & 4.78 & 4.91 & 5.10 & 4.95 & treatment \\
\hline$A$ & 1.412 & 1.482 & 1.580 & 1.609 & 30 days after \\
\hline$C, \mathrm{~g} / 1$ & 4.81 & 5.01 & 5.15 & 5.42 & treatment \\
\hline
\end{tabular}

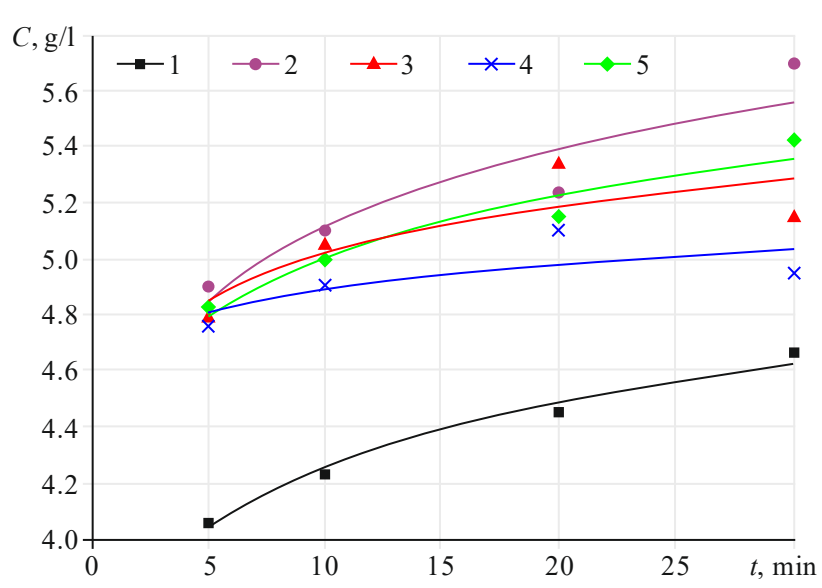

Figure 3. Changing the content of conventional metal in the leaching solution depending on the time of reaction and the solution mature over time after treatment with a cavitator for 5 minutes: 1 - initial state of the solution (before treatment); 2-after treatment; 3-2 hours after treatment; 4-24 hours after treatment; 5 - 30 days after treatment

During treatment, the evolution of sulphur dioxide was observed. The data presented in Table 1 show that initially the activity of the solution within 5 minutes of leaching increased by $20.5 \%$, and after 10 minutes - by $21 \%$. In general, it can be considered that the primary activity remains constant immediately after treatment of the electrolyte with a cavitator and for 30 days.

The data on the properties of the leaching sulphuric acid solution after treatment in a cavitation plant for 10 minutes are shown in Table 3 and Figure 4.
Table 3. Changing the optical density (A) over time and the conventional metal content in the leaching solution (C) after treatment of the electrolyte with a cavitator for 10 minutes

\begin{tabular}{cccccc}
\hline $\begin{array}{c}\text { Parame- } \\
\text { ters }\end{array}$ & 5 & 10 & 20 & 30 & $\begin{array}{c}\text { Type and time } \\
\text { of the solution } \\
\text { mature }\end{array}$ \\
\hline$A$ & 1.348 & 1.428 & 1.540 & 1.581 & $\begin{array}{c}\text { Initial } \\
\text { Reaction time, min }\end{array}$ \\
$C, \mathrm{~g} / 1$ & 4.11 & 4.36 & 4.61 & 4.68 & solution \\
$A$ & 1.388 & 1.485 & 1.575 & 1.590 & After \\
$C, \mathrm{~g} / 1$ & 5.14 & 5.17 & 5.29 & 5.36 & treatment \\
$A$ & 1.40 & 1.463 & 1.579 & 1.630 & 2 hours after \\
$C, \mathrm{~g} / 1$ & 4.8 & 5.09 & 5.23 & 5.40 & treatment \\
$A$ & 1.409 & 1.430 & 1.500 & 1.538 & 24 hours after \\
$C, \mathrm{~g} / 1$ & 4.62 & 4.78 & 5.09 & 5.23 & treatment \\
$A$ & 1.491 & 1.548 & 1.615 & 1.636 & 30 days after \\
$C, \mathrm{~g} / 1$ & 4.85 & 5.15 & 5.45 & 5.42 & treatment \\
\hline & & & & &
\end{tabular}

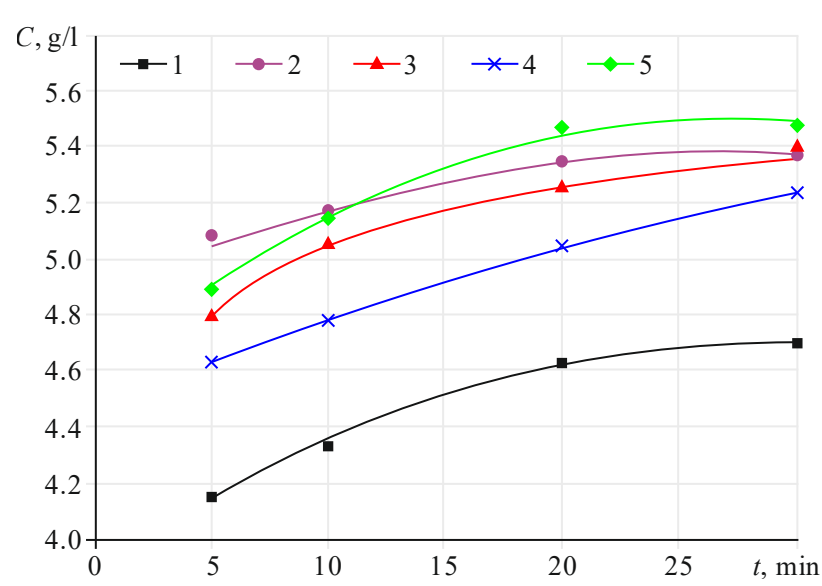

Figure 4. Changing the content of conventional metal in the leaching solution depending on the time of reaction and the solution mature over time after treatment with a cavitator for 10 minutes: 1 -initial state of the solution (before treatment); 2 -after treatment; 3-2 hours after treatment; 4-24 hours after treatment; 5 - 30 days after treatment

An increase in the time of the solution treatment up to 10 minutes has led to an increase in the activity by $25 \%$ for 5 minutes of the leaching reaction. In the course of the solution treatment, there was a noticeable evolution of sulphur dioxide. This is caused by a slight evaporation of sulphuric acid. Within 2 hours, the solution activity has decreased to $8.0 \%$ and remained in this state for a long time.

The experiments conducted on the use of cavitation to activate the leaching solution have confirmed an increase in the sulphuric acid activity after treatment in a cavitation plant. However, the depth of the boreholes of uranium deposits in the south of the Republic of Kazakhstan reaches $700 \mathrm{~m}$ and deeper, where the aqueous solution pressure at this depth is 70 atmospheres or $7 \mathrm{MPa}$, and the formation water temperature in the deposits reaches $35^{\circ} \mathrm{C}$.

At the same time, after leaching, the pregnant solution goes through a sorption process, and the sorbent goes through a desorption process. Therefore, further research should be carried out to establish the influence of the solution activation on the processes of sorption and desorption.

Moreover, according to the research results, it can be seen that the leaching solution activity increases at the 
initial moment, then it noticeably decreases within 24 hours of mature, and an increase is observed after 1 month. In this regard, in the future there is a need to conduct a research to set the changes in the rheological properties of the leaching solution over time, as well as the influence of growing pressure and temperature on the solution activity after its treatment with a cavitator.

\section{CONCLUSIONS}

The studies have established that the leaching solution activation leads to an increase in the sulphuric acid activity after treatment in a cavitation plant.

In order to activate the leaching solution, it is proposed to carry out cavitation treatment of an acid before to additionally fortify the mother solution. Thus, the volume of the treated solution and the cost of manufacturing and operating the cavitator are reduced.

The solution activation leads to an increase in the valuable component content from 18 to $26 \%$ in the pregnant solution and its activity is maintained for a long time (up to 30 days)

The proposed technology is characterized by low capital costs, is easily integrated into the existing system and is absolutely environmentally friendly.

The technology of a leaching solution activation in borehole in-situ leaching of uranium or in heap leaching of non-ferrous and precious metals will increase the ratio of recovery efficiency.

To implement this technology in a production environment, an activator should be manufactured consisting of an engine and a generator unit. The parameters of a plant will depend on the volume of solution supplied for leaching.

\section{ACKNOWLEDGEMENTS}

This research was conducted as part of the business contract implementation with JV "Akbastau", No. 281/ Akb-16 of 23 December, 2016 and as part of the research-development work "Development of technology for mining and extraction of gold from poor ore veins", performed within the framework of the program "Modernization of technologies and production in the mining and mining-processing industries of the republic of Kazakhstan", No. 266 of 28 March, 2018. The authors express their gratitude to Doctor of Technical Sciences, Professor H.A. Yusupov, Professor G.G. Kurapov and to Chief Research Scientist S.A. Yusupov for assistance and valuable advice in conducting this research.

\section{REFERENCES}

Anisimov, O., Symonenko, V., Cherniaiev, O., \& Shustov, O. (2018). Formation of safety conditions for development of deposits by open mining. E3S Web of Conferences, (60), 00016.

https://doi.org/10.1051/e3sconf/20186000016

Arens, V.Kh. (1986). Skvazhinnaya dobycha poleznykh iskopaemykh. Moskva, Rossiya: Nedra.

Armstrong, D., \& Jeuken, B. (2009). Management of in-situ recovery (ISR) mining fluids in a closed aquifer system. $A b$ stracts of the International Mine Water Conference, 703-712.
Barchenkov, V.V. (2016). Intensivnoe tsianirovanie graviokontsentrata na novoy ustanovke SLR kompanii Sepro Mineral Systems. Retrieved from https://zolotodb.ru/article/11435

Catchpole, M., \& Robins, W. (2015). Future global energy demand. AusIMM Bulletin.

Ceccio, S.L. (2010). Friction drag reduction of external flows with bubble and gas injection. Annual Review of Fluid Mechanics, 42(1), 183-203.

https://doi.org/10.1146/annurev-fluid-121108-145504

Golik, V.I., \& Kultyshev, V.I. (2011). Istoriya i perspektivy vyshchelachivaniya urana. Gornyy InformatsionnoAnaliticheskiy Byulleten', (7), 138-143

Hoummady, E., Golfier, F., Cathelineau, M., Truche, L., Durupt, N., Blanvillain, J.J., \& Lefevre, E. (2017). A multianalytical approach to the study of uranium-ore agglomerate structure and porosity during heap leaching. Hydrometallurgy, (171), 33-43. https://doi.org/10.1016/j.hydromet.2017.04.011

Kalabin, A.I. (1981). Dobycha poleznykh iskopaemykh podzemnym vyshchelachivaniem $i$ drugimi geotekhnologicheskimi metodami. Moskva, Rossiya: Atomizdat.

Kalybekov, T., Sandibekov, M., Rysbekov, K., \& Zhakypbek, Y. (2019). Substantiation of ways to reclaim the space of the previously mined-out quarries for the recreational purposes. E3S Web of Conferences, (123), 01004. https://doi.org/10.1051/e3sconf/201912301004

Karaganov, V.V., \& Uzhkenova, B.S. (2002). Kuchnoe vyshchelachivanie zolota - zarubezhnyy opyt $i$ perspektivy razvitiya. Moskva, Rossiya: Vserossiyskiy institut ekonomiki mineral'nogo syr'ya i nedropol'zovaniyam, TOO "Geointsentr".

Kashuba, S.G., \& Leskov, M.I. (2014). Kuchnoe vyshchelachivanie $\mathrm{v}$ rossiyskoy praktike - obzor opyta i analiz perspektiv. Zoloto i Tekhnologii, 1(23), 1-8.

Knepp, R., Deyli, Dzh., \& Khemmit, F. (1974). Kavitatsiya. Moskva, Rossiya: Mir.

Koshkolda, K.N., Pimenov, M.K., \& Atakulov, T. (1988). Puti intensifikatsii podzemnogo vyshchelachivaniya. Moskva, Rossiya: Energoatomnadat.

Kubota, A., Kato, H., \& Yamaguchi, H. (1992). A new modelling of cavitating flows: a numerical study of un-steady cavitation on a hydrofoil section. Journal of Fluid Mechanics, 240(3), 59-96. https://doi.org/10.1017/s002211209200003x

Lauterborn, W. (1980). Optic cavitation. Journal of Physics, (41), 273-280.

Medunić, G., Mondol, D., Rađenović, A., \& Nazir, S. (2018). Review of the latest research on coal, environment, and clean technologies. Rudarsko Geolosko Naftni Zbornik, 33(3), 13-21.

https://doi.org/10.17794/rgn.2018.3.2

Menshov, O., Kuderavets, R., Popov, S., Homenko, R., Sukhorada, A., \& Chobotok, I. (2016). Thermomagnetic analyzes of soils from the hydrocarbon fields. Visnyk of Taras Shevchenko National University of Kyiv. Geology, 73(2), 33-37. https://doi.org/10.17721/1728-2713.79.05

Miller, D. (2007). Overview of experimental studies of biological effects of medical ultrasound caused by gas body activation and inertial cavitation. Progress in Biophysics and Molecular Biology, 93(1-3), 314-330.

Petersen, J. (2016). Heap leaching as a key technology for recovery of values from low-grade ores - A brief overview. Hydrometallurgy, (165), 206-212. https://doi.org/10.1016/j.hydromet.2015.09.001

Prentice, P., Cuschieri, A., Dholakia, K., Prausnitz, M., \& Campbell, P. (2005). Membrane disruption by optically controlled microbubble cavitation. Nature Physics, 1(2), 107-110. https://doi.org/10.1038/nphys 148 
Rooze, J., Rebrov, E.V., Schouten, J.C., \& Keurentjes, J.T.F. (2013). Dissolved gas and ultrasonic cavitation - A review. Ultrasonics Sonochemistry, 20(1), 1-11. https://doi.org/10.1016/j.ultsonch.2012.04.013

Sekisov, A.G., Rubtsov, Yu.I., \& Lavrov, A.Yu. (2016). Aktivatsionnoe kuchnoe vyshchelachivanie dispersnogo zolota iz malosul’ fidnykh rud. Zapiski Gornogo Instituta, (217), 1-232.

Shcherbakov, P., Tymchenko, S., Buhrym, O., \& Klymenko, D. (2019). Research into the crushing and grinding processes of iron ore with its simultaneous effect by mechanical load and electric field of ultra-high frequency. E3S Web of Conferences, (123), 01030 https://doi.org/10.1051/e3sconf/201912301030

Sukhodolov, A.P. (2010). Mirovye zapasy urana: perspektivy syr'yevogo obespecheniya atomnoy energetiki. Izvestiya Irkutskoy Gosudarstvennoy Ekonomicheskoy Akademii, 4(72), 166-169.

Sukhov, V., Suyarko, V., Niemets, K., \& Matveyev, A. (2018). Hydrogeodynamic processes in carbonate rocks. Part II. Karst and its influence on geological environment. Visnyk of V.N. Karazin Kharkiv National University - Series Geology, Geography, Ecology, (48), 173-184. https://doi.org/10.26565/2410-7360-2018-48-15

Tan, Q., Deng, C., \& Li, J. (2016). Innovative application of mechanical activation for rare earth elements recovering:
Process optimization and mechanism exploration. Scientific Reports, (6), 19961.

Vogel, A., Busch, S., \& Parlitz, U. (1996). Shock wave emission and cavitation bubble generation by picosecond and nanosecond optical breakdown in water. The Journal of the Acoustical Society of America, 100(1), 148-165. https://doi.org/10.1117/12.209939

Wadsworth, M., Zhu, X., Thompson, J., \& Pereira, C. (2000). Gold dissolution and activation in cyanide solution: Kinetics and mechanism. Hydrometallurgy, 57(1), 1-11. https://doi.org/10.1016/s0304-386x(00)00084-0

Ye, Y.J., Ding, D.X., Li, G.Y., Song, J.B., \& Li, F. (2013). Regularities for liquid saturated seepage in uranium ore heap for heap leaching. Rock and Soil Mechanics, 34(8), 2243-2248.

Yusupov, K.A., Elzhanov, E.A., Aliev, S.B., \& Dzhakupov, D.A. (2017). Application of ammonium bifluoride for chemical treatment of wells in underground uranium leaching. Gornyi Zhurnal, (4), 57-60. https://doi.org/10.17580/gzh.2017.04.11

Zabel'skiy, V.K. (1981). Perspektivy primeneniya skvazhinnoy tekhnologii podzemnogo vyshchelachivaniya pri razrabotke mestorozhdeniy poleznykh iskopaemykh. Gornyi Zhurnal, (7), 48-52.

\section{ДОСЛІДЖЕННЯ ЗМІНИ АКТИВНОСТІ ВИЛУГОВУЮЧОГО РОЗЧИНУ ПІСЛЯ ОБРОБКИ КАВІТАТОРОМ}

\section{Е. Абен, Ж. Маркенбаєв, Н. Хайруллаєв, С. Мирзахметов, Х. Абен}

Мета. Підвищення вмісту корисного компоненту в продуктивному розчині за рахунок активації вилуговуючого розчину кавітаційною обробкою при підземному свердловинному вилуговуванні.

Методика. Для отримання ефекту кавітації була виготовлена лабораторна кавітаційна установка. Дослідження 3 активації сірчанокислотного розчину кавітацією проведені на розчинах з вмістом кислоти 10 г/л. Дослідження зміни активності сірчанокислотного розчину при обробці кавітатором проводили протягом 3 хвилин (24 проходи через кавітатор), 5 хвилин (40 проходів), 10 хвилин (80 проходів) і 20 хвилин (160 проходів). Аналіз вмісту корисного компонентау в розчині вели з використанням фотоелектричного фотометра КФК-3-“ЗОМС”.

Результати. Виконані лабораторні дослідження зі встановлення впливу процесу кавітації на активність вилуговуючого розчину при різному ступені активації та часу реакції. Дослідженнями встановлено, що для активації вилуговуючого розчину пропонується проводити кавітаційну обробку сірчаної кислоти перед дозміцненням маточного розчину, що сприятиме підвищенню їі активності. Активація розчину призводить до збільшення вмісту корисного компоненту в продуктивному розчині від 18 до 26\% і їі активність зберігається протягом тривалого часу (до 30 днів).

Наукова новизна. Отримано нові залежності, що відображають характер зміни вмісту корисного компоненту в продуктивному розчині від часу реакції та ступеня активації розчину.

Практична значимість. Запропонований спосіб активації призводить до збільшення вмісту корисного компоненту в продуктивному розчині у порівнянні з базовою технологією, при цьому активність зберігається протягом тривалого часу. Запропонована технологія відрізняється низькими капітальними витратами, легко інтегрується в існуючу систему й екологічно абсолютно безпечна.

Ключові слова: кавітація, активність, сірчана кислота, вилуговуючий розчин, продуктивний розчин, умовний метал

\section{ИССЛЕДОВАНИЕ ИЗМЕНЕНИЯ АКТИВНОСТИ ВЫЩЕЛАЧИВАЮЩЕГО РАСТВОРА ПОСЛЕ ОБРАБОТКИ КАВИТАТОРОМ}

\section{Э. Абен, Ж. Маркенбаев, Н. Хайруллаев, С. Мирзахметов, Х. Абен}

Цель. Повышение содержания полезного компонента в продуктивном растворе за счет активации выщелачивающего раствора кавитационной обработкой при подземном скважинном выщелачивании.

Методика. Для получения эффекта кавитации была изготовлена лабораторная кавитационная установка. Исследования по активации сернокислотного раствора кавитацией проведены на растворах с содержа-нием кислоты 10 г/л. Исследования изменения активности сернокислотного раствора при обработке кавитатором проводили в течение 3 минут (24 прохода через кавитатор), 5 минут (40 проходов), 10 минут (80 проходов) и 20 минут (160 проходов). Анализ содержания полезного компонента в растворе вели с использованием фотоэлектрического фотометра КФК-3-“ЗОМС”. 
Результаты. Выполнены лабораторные исследования по установлению влияния процесса кавитации на активность выщелачивающего раствора при различной степени активации и времени реакции. Исследованиями установлено, что для активации выщелачивающего раствора предлагается проводить кавитационную обработку серной кислоты перед доукреплением маточного раствора, что способствует повышению ее активности. Активация раствора приводит к увеличению содержания полезного компонента в продуктивном растворе от 18 до $26 \%$ и ее активность сохраняется длительное время (до 30 дней).

Научная новизна. Получены новые зависимости, отражающие характер изменения содержания полезного компонента в продуктивном растворе от времени реакции и степени активации раствора.

Практическая значимость. Предложенный способ активации приводит к увеличению содержания полезного компонента в продуктивном растворе по сравнению с базовой технологией, при этом активность сохраняется длительное время. Предлагаемая технология отличается низкими капитальными затратами, легко интегрируется в существующую систему и экологически абсолютно безопасна.

Ключевые слова: кавитация, активность, серная кислота, выщелачивающий раствор, продуктивный раствор, условный металл

\section{ARTICLE INFO}

Received: 8 August 2019

Accepted: 28 November 2019

Available online: 4 December 2019

\section{ABOUT AUTHORS}

Erbolat Aben, Candidate of Technical Sciences, Senior Teacher of the Mining Department, Satbayev University, 22 Satpaev St, 50013, Almaty, Kazakhstan. E-mail: aek@mail.ru

Zhumagaly Markenbayev, Master of Technical Sciences, General Director of the "DP "Ortalyk" LLP, 27a BaidibekBi Ave., 160013, Shumkent, Kazakhstan. E-mail: MJD@akbastau.kz

Nursultan Khairullaev, Master of Technical Sciences, PhD Student of the Mining Department, Satbayev University, 22 Satpaev St, 50013, Almaty, Kazakhstan. E-mail: khayrullaev.n@,gmail.com

Sayfulmalik Myrzakhmetov, Candidate of Technical Sciences, Senior Teacher of the Mining Department, Satbayev University, 22 Satpaev St, 50013, Almaty, Kazakhstan. E-mail: myrzakhmetov s@mail.ru

Khayrulla Aben, Candidate of Technical Sciences, Mining engineer of the KAZ Minerals, 8 Omarova St, 50045, Almaty, Kazakhstan. E-mail: abencl@,mail.ru 